\title{
The Web-Based Outpatient Information System at Community Health Center
}

\author{
Vini Alvianita, Phong Thanh Nguyen, M. Ilayaraja, K. Shankar, Satria Abadi, Wahidah Hashim, \\ Andino Maseleno
}

\begin{abstract}
Community Health Center is one of the agencies engaged in public health services. As technology advances in the health sector, an application is needed to accelerate and facilitate the Community Health Center in delivering information about Community Health Center and can be accessed by the public without limited space and time. Therefore this final project aims to provide information by improving the quality of Community Health Center by facilitating websites so that they can support the development of Community Health Center services. With the establishment of a Web-Based Outpatient Patient Information System at Talangpadang Community Health Center, it is hoped that it can facilitate the community to get the information needed, related to the Talangpadang Community Health Center. This application is Web-based, using the Web programming language, PHP, MYSQL.
\end{abstract}

Keywords : internet, information system.

\section{INTRODUCTION}

\subsection{Research Background}

Internet is a computer network that can connect companies with the public domain such as individuals, communities, institutions, and organizations [1]

The rapid development of information has placed Indonesia as part of the world information society, which requires the use of information technology [2].

Along with the increasing development of technology in the health sector, an application is needed to accelerate and make it easier for the public to access Talangpadang Community Health Center Information.

With the development of current technology, making slow activities become fast, practical, and easy to do [3]. The development of these technologies also affects the system of

Revised Manuscript Received on July 22, 2019

* Correspondence Author

Vini Alvianita, Department of Information Systems, STMIK Pringsewu, Lampung, Indonesia.

Phong Thanh Nguyen*, Department of Project Management, Ho Chi Minh City Open University, Vietnam. E-mail: phong.nt@ou.edu.vn

M. Ilayaraja, Department of Computer Science and Information Technology, Kalasalingam Academy of Research and Education, Krishnankoil, India. E-mail: ilayaraja.m@klu.ac.in

K. Shankar, Department of Computer Applications, Alagappa University, Karaikudi, India. E-mail: shankarcrypto@gmail.com

Satria Abadi, Department of Information Systems, STMIK Pringsewu, Lampung, Indonesia. Universiti Tenaga Nasional, Malaysia.

Andino Maseleno, Institute of Informatics and Computing Energy, Universiti Tenaga Nasional, Malaysia.
Wahidah Hashim, Institute of Informatics and Computing Energy,

activities at Community Health Center. Almost all activities in a company agency use an information technology-based system, including in the field of health in hospitals for outpatient services [4].

This application can make easier for the public to obtain information so that people do not have to go to the Community Health Center, related to getting information [5]. With this application, the public can access information remotely.

\subsection{Research Problem}

The formulation of the problem in this project are :

a. It is difficult for the community to get information about outpatient services at Jalan Padas in the Talangpadang Community Health Center because of limited working hours.

b. Information services are limited to only around the Community Health Center.

\subsection{Research Objective}

The research objectives in this project are :

a. As a requirement in completing the Bachelor Degree education program at the Pringsewu College of Information and Computer Management.

b. It can facilitate the public in accessing information about Outpatient services at Talangpadang Community Health Center.

c. Public can find out the health information

This system only serves :

a. Publication of Outpatient service information at Talangpadang Community Health Center.

b. Publication of health information..

\section{LITERATURE REVIEW}

\subsection{Definition of System}

The system is a logical and rational procedure for designing a series of components that relate to one another with the intent as a unit to achieve a predetermined goal [6]. The system is a series of parts that are interconnected and dependent in such a way so that the interaction and mutual influence of one part will affect the whole [7]. 


\subsection{Definition of Information}

Before discussing the definition of information, it is necessary to know the meaning of data, because basically between data and information are two things that cannot be separated [8]. Data can be interpreted as symbols, signs and so on that have not been processed so that it is not Information is data that has been processed so that it is useful for decision making [9].

\subsection{Definition of Information System}

Information Systems are a combination of humans, facilities or technological tools, media, procedures and controls that intend to organize important communication networks, the process of certain and routine transactions, assisting internal and external management and users and providing the basis for appropriate decision making [10].

Information systems are a tool for presenting information in such a way that it is useful for recipients [11]. The aim is to present information for decision making in planning, initiating, organizing, controlling the operations of a company that presents organizational synergy in the process [12].

\subsection{Community Health Center}

Community Health Center is a functional organization which organizes health efforts that are comprehensive, integrated, equitable, acceptable and affordable by the community, with the active participation of the community and using the results of the development of appropriate science and technology, with costs that can be borne by the government and society. Health efforts are carried out by focusing on services for the wider community to achieve optimal health levels, without neglecting the quality of services to individuals.

\subsection{MySQL}

MySQL is software that is classified as a DBMS (DataBase Management System) that is open source. An open-source states that this software is equipped with source code (the code used to create MySQL), which the form is executable and the code can be run directly in the operating system, and can be obtained by downloading.

\subsection{HTML (Hypertext Markup Language)}

HTML is a system that uses simple commands in the ACCII text document standard for provide an integrated visual display. In other words, a document is created in several word processing and storing programs in the usual ASCII format but can be created into a home page with a few HTML commands added.

\subsection{PHP}

PHP is a server-side script that is added to HTML. PHP stands for Personal Home Page Tool. This script will make an application integrated into HTML, so that a web page is no longer static, but becomes dynamic.

\section{DATA COLLECTING TECHNIQUE}

Research methodology is the unity of methods, procedures, work concepts, rules, postulates, which are used by science, art or other disciplines in conducting the research [13].
The research methodology used is the Observation Method.

\section{a. Observation}

Observation is a method of collecting data by observation directly an activity or place that is used as the object of research [14].

The researcher did the direct observations by visiting the Talangpadang Community Health Center to obtain information and data sources to be used [15].

\section{b. Interview}

Interviews are a way of collecting data by asking questions and meeting face to face with the person interviewed / respondent [16]. In this method, the researcher conducted a question and answer directly with Talangpadang Community Health Center staff [17].

\section{c. Document Review}

To get the data needed, the researcher also looked at the documents [18] belonging to the Talangpadang Community Health Center.

\section{RUNNING SYSTEM ANALYSIS}

\subsection{Description}

1. Public who need information [19] about the Community Health Center should come directly to the Talangpadang Community Health Center.

2. Public who need information should make questions [20].

3. Then the questions are submitted to the Community Health Center staff [21].

4. The Community Health Center staff gives information on questions raised by the community [22].

5 . Then the information is distributed to the public in need [23].

For more details, please see the following Flowchart Document: 


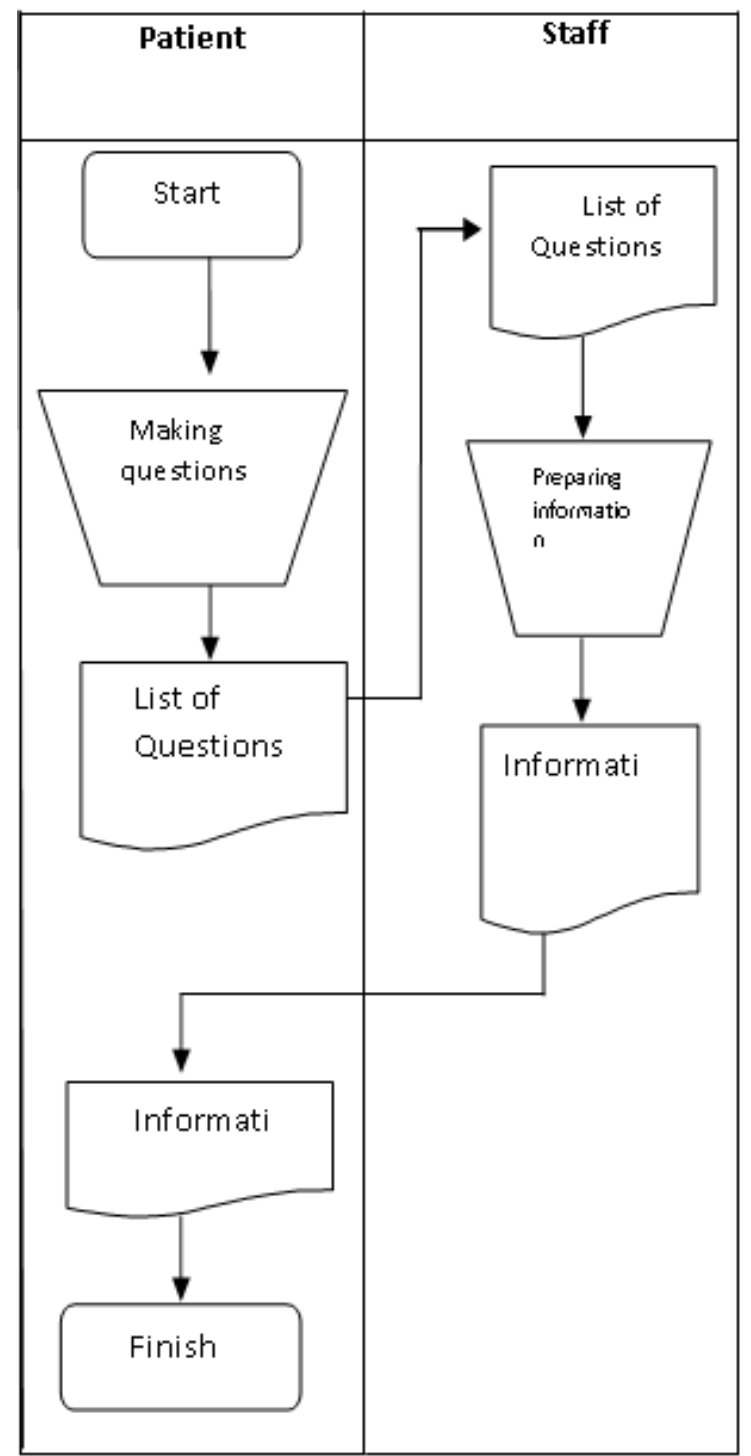

Figure 1: DAD Sistem yang sedang berjalan

\section{Weakness of Running System Analysis:}

1. Public who need information should come directly to the Community Health Center.

2. Weak information given because of limited working hours.

3. The system that runs manually is time-consuming, less effective and efficient

\section{PROPOSED SYSTEM DESIGN}

1. Community Health Center provides information to the public that can be accessed directly by the community through the website.

2. Information can be accessed anytime, anywhere, without limited work hours.

For detail information, it can be seen in the Flowchart Document as follows:

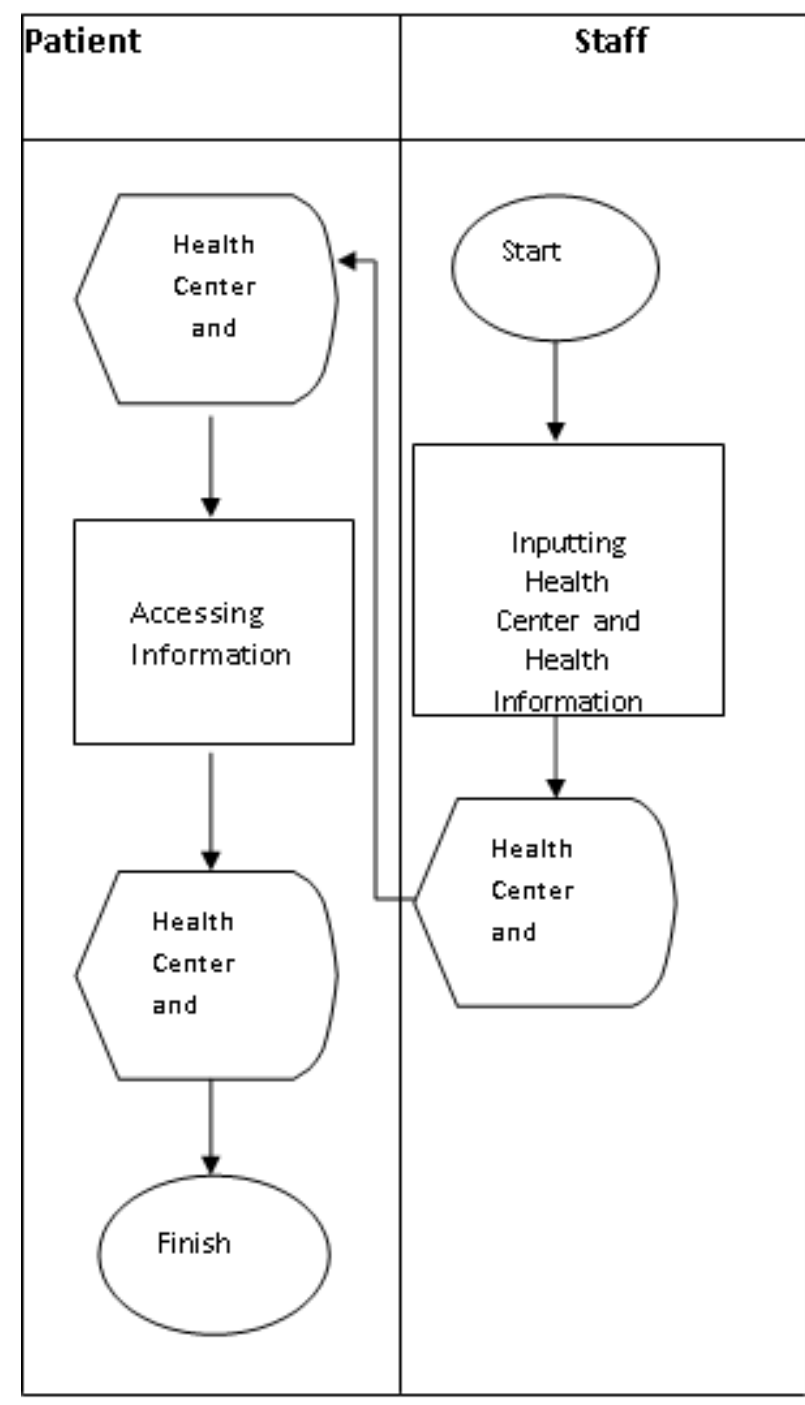

Figure 2: DAD Proposed System

\section{RESULT}

The results of the analysis conducted by the researcher above can provide convenience to the Community Health Center staff in publishing Health Center information, and Outpatient information at Health Center, without limited working hours. So the community can access information anytime, anywhere, without limited work hours. So the community can access the information about Talangpadang Health Center anywhere and anytime.

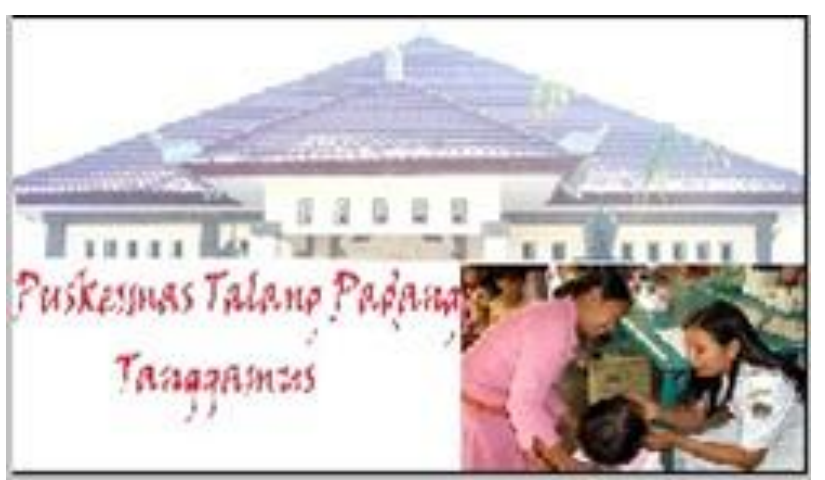

Figure3: Main Page

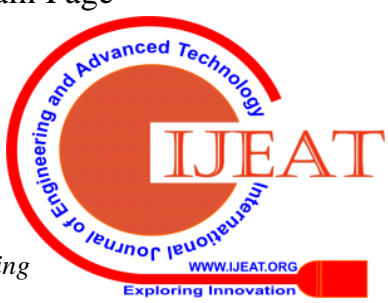




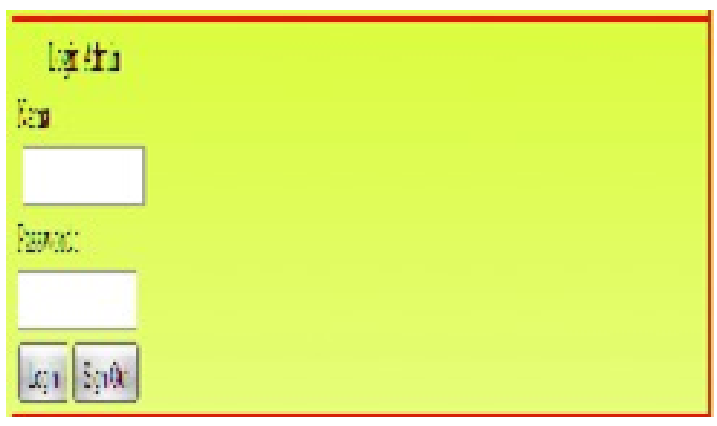

Figure 4: Admin page

\section{CONCLUSION}

Based on the analysis of research conducted by the researcher, the conclusions as follows :

1. Public should come directly to the Community Health Center to get information. This activity is time-consuming, ineffective, and efficient. By using a web-based outpatient at Talangpadang Community Health Center so the public can access the information easier which provided in Talangpadang Health Center.

2. Submission of information can be faster, and extensive by using Outpatient Information System at Talangpadang Community Health Center.

3. By using the Outpatient Information System at Talangpadang Community Health Center, the public can access information easily, quickly, anywhere and anytime.

\section{REFERENCES}

1. Haseeb, M., Kot, S., Hussain, H., \& Jermsittiparsert, K. 2019. "Impact of Economic Growth, Environmental Pollution, and Energy Consumption on Health Expenditure and R and D Expenditure of ASEAN Countries." Energies 12 (19): 3598.

2. Huda, S., Tsani, I., Syazali, M., Umam, R., \& Jermsittiparsert, K. 2020. "The Management of Educational System Using Three Law Auguste Comte: A Case of Islamic Schools.” Management Science Letters 10 (3) (In press), DOI: 10.5267/j.msl.2019.9.018.

3. Usak, M., Kubiatko, M., Shabbir, M., Dudnik, O., Jermsittiparsert, K., \& Rajabion, L. 2019. "Health Care Service Delivery Based on the Internet of Things: A Systematic and Comprehensive Study." International Journal of Communication Systems 32 (14): e4179.

4. Jermsittiparsert, K., Ambarita, D., Mihardjo, L., \& Ghani, E. 2019. "Risk-Return through Financial Ratios as Determinants of Stock Price: A Study from ASEAN Region." Journal of Security and Sustainability Issues 9 (1): 199-210.

5. Thabhiranrak, T. \& Jermsittiparsert, K. 2019. "Towards Sustainable Functioning of Organization: Women Empowernment and Corporate Management Culture." Journal of Security and Sustainability Issues 9 (1): 321-332.

6. Maseleno, A., Hardaker, G., Sabani, N., \& Suhaili, N. (2016). Data on multicultural education and diagnostic information profiling: Culture, learning styles and creativity. Data in brief, 9, 1048.

7. Maseleno, A., Huda, M., Jasmi, K. A., Basiron, B., Mustari, I., Don, A. G., \& bin Ahmad, R. (2019). Hau-Kashyap approach for student's level of expertise. Egyptian Informatics Journal, 20(1), 27-32.

8. Maseleno, A., Huda, M., Siregar, M., Ahmad, R., Hehsan, A., Haron, Z., ... \& Jasmi, K. A. (2017). Combining the previous measure of evidence to educational entrance examination. Journal of Artificial Intelligence, 10(3), 85-90.

9. Chienwattanasook, K. \& Jermsittiparsert, K. 2019. "Impact of Entrepreneur Education on Entrepreneurial Self-Employment: A Case Study from Thailand." Polish Journal of Management Studies 19 (1): 106-116

10. Jermsittiparsert, K., Sutduean, J., Sriyakul, T., \& Khumboon, R. 2019. "The Role of Customer Responsiveness in Improving the External Performance of an Agile Supply Chain.” Polish Journal of Management Studies 19 (2): 206-217.

11. Jermsittiparsert, K., Sutduean, J., \& Sriyakul, T. 2019. "Effect of Service Innovation and Market Intelligence on Supply Chain
Performance in Indonesian Fishing Industry." Industrial Engineering \& Management Systems 18 (3): 408-417.

12. Jermsittiparsert, K., Namdej, P., \& Somjai, S. 2019. "Green Supply Chain Practices and Sustainable Performance: Moderating Role of Total Quality Management Practices in Electronic Industry of Thailand.” International Journal of Supply Chain Management 8 (3): 33-46.

13. Somjai, S. \& Jermsittiparsert, K. 2019. "The Trade-off between Cost and Environmental Performance in the Presence of Sustainable Supply Chain.” International Journal of Supply Chain Management 8 (4): 237-247.

14. Jermsittiparsert, K. \& Sawasdee, A. 2012. "Formal Education for Non-Thai or Undocumented Person in Thailand amidst the Challenge of Nationalism and Transnationalism: A Case Study of Wat Sirimongkhol School, Samut Sakhon Province." Kasetsart Journal - Social Sciences 33 (2): 203-213.

15. Chienwattanasook, K., Wattanapongphasuk, W., Prianto, A., \& Jermsittiparsert, K. 2019. "Corporate Entrepreneurship and Business Performance of Logistic Companies in Indonesia." Industrial Engineering \& Management Systems 18 (3): 538-547.

16. Dawabsheh, M., Hussein, A., \& Jermsittiparsert, K. 2019. "The Triangular Relationship between TQM, Organizational Excellence and Organizational Performance: A Case of Arab American University Palestine." Management Science Letters 9 (6): 921-932.

17. Jermsittiparsert, K., Siam, M., Issa, M., Ahmed, U., \& Pahi, M. 2019. "Do Consumers Expect Companies to Be Socially Responsible? The Impact of Corporate Social Responsibility on Buying Behavior." Uncertain Supply Chain Management 7 (4): 741-752.

18. Syazali, M., Putra, F., Rinaldi, A., Utami, L., Widayanti, Umam, R., \& Jermsittiparsert, K. 2019. "Partial Correlation Analysis Using Multiple Linear Regression: Impact on Business Environment of Digital Marketing Interest in the Era of Industrial Revolution 4.0.' Management Science Letters 9 (11): 1875-1886.

19. Sae-Lim, P. \& Jermsittiparsert, K. 2019. "Is the Fourth Industrial Revolution a Panacea? Risks toward the Fourth Industrial Revolution: Evidence in the Thai Economy." International Journal of Innovation, Creativity and Change 5 (2): 732-752.

20. Chatchawanchanchanakij, P., Arpornpisal, C., \& Jermsittiparsert, K. 2019. "The Role of Corporate Governance in Creating a Capable Supply Chain: A Case of Indonesian Tin Industry." International Journal of Supply Chain Management 8 (3): 854-864.

21. Hartinah, S., Suharso, P., Umam, R., Syazali, M., Lestari, B., Roslina, R., \& Jermsittiparsert, K. 2020. "Teacher's Performance Management: The Role of Principal's Leadership, Work Environment and Motivation in Tegal City, Indonesia." Management Science Letters 10 (1): 235-246.

22. Haseeb, M., Hussain, H., Slusarczyk, B., \& Jermsittiparsert, K. 2019. "Industry 4.0: A Solution towards Technology Challenges of Sustainable Business Performance.” Social Sciences 8 (5): 184.

23. Haseeb, M., Hussain, H., Kot, S., Androniceanu, A., \& Jermsittiparsert, K. 2019. "Role of Social and Technological Challenges in Achieving a Sustainable Competitive Advantage and Sustainable Business Performance.” Sustainability 11 (14): 3811. 